\title{
SUICIDE AS AN INDICATOR OF THE PUBLIC MENTAL HEALTH IN UKRAINE (INCLUDING PERIOD OF COVID-19)
}

DOI: 10.36740/WLek202012208

\author{
Vladyslava S. Batyrgareieva', Alina V. Kalinina', Andriy M. Babenko² \\ ${ }^{1}$ ACADEMICIAN STASHIS SCIENTIFIC RESEARCH INSTITUTE FOR THE STUDY OF CRIME PROBLEMS NATIONAL ACADEMY OF LAW SCIENCES OF UKRAINE, \\ KHARKIV, UKRAINE \\ 20DESSA STATE UNIVERSITY OF INTERNAL AFFAIRS, ODESA, UKRAINE
}

\begin{abstract}
The aim: This article aims to analyze the rates of suicide as an indicator of public mental health, to consider the suicidal map of the territory of Ukraine (including to check the manifestation of such a territorial characteristic as the Albanian paradox); calculate the price of suicide for the socio-economic development of the Ukrainian state, consider the risks of suicide that have arisen as social and criminological consequences of the COVID-19 pandemic.

Materials and methods: The study is based on the analytical materials of the Ministry of Health of Ukraine and the WHO; the information and analytical data of the General Prosecutor's Office of Ukraine, the State Statistics Service of Ukraine and sectoral statistics for the period of 2015-2019, etc. The article is based on dialectical, analytical, synthetic, comparative, statistical, cartographic, and sociological methods of research and the method of potential demography. The theoretical basis of the article is specialized literature on medicine, suicidology, law, sociology, and cartography.

Results: In Ukraine, the death rate from suicide in recent years averages $1.1 \%$ of the total number of deaths. The rate of suicide decline in Ukraine has slowed significantly over the past five years, which is an alarming symptom.

There are almost strict proportions between male and female suicide (men commit four out of five suicides). The level of self-harm per 100,000 population of Ukraine remains almost stable, indicating a severe demographic crisis in Ukraine.

Women in Ukraine are less likely to commit suicide than in European countries. In Ukraine in recent years, contrary to European trends, suicide has dominated among the elderly aged $65+$. The number of years of potential life loss for male and female suicides in Ukraine is 103 thousand, and the number of working years is almost 100 thousand. The losses for Ukraine from the unlived life of those who died as a result of suicide in 2019 are almost USD 341 billion.

Conclusions: In 2019, suicides accounted for almost 21\% of deaths from external causes among Ukraine's population. The most intense suicidal situation is observed in the central part of the country's geographical map along the imaginary vertical axis “North-South” (Kherson, Chernihiv, Cherkasy, Vinnytsia, Zaporizhia, Kirovohrad, Sumy, Poltava, Dnipropetrovsk, Mykolaiv regions).

During the COVID-19 pandemic, many additional factors increase the risk of suicide among individuals who are at heightened risk of suicide or are actively suicidal, and among the general population.
\end{abstract}

KEY WORDS: public mental health, suicide, vulnerable populations, COVID-19 pandemic

Wiad Lek. 2020;73(12 p. II):2743-2751

\section{INTRODUCTION}

One of the generally accepted indicators of public mental health, socio-psychological well-being, quality of life of a population or a specific region of the world, or a country or administrative-territorial unit is the indicator of suicide mortality. The level of suicides and their dynamics is also an indirect indicator of the number of people needing urgent treatment and suicidal prevention care [1]. Therefore, the problem of the existence of suicide as a social phenomenon traditionally attracts the attention of the public, church, scientific community, and the state [2, p. 23], because nowadays it acquires immense phenomenological, existential, and philosophical significance.

Suicide is one of the major health problems, and the global suicide mortality rate amounts to $1.4 \%$ of all deaths worldwide. Most suicides are related to psychiatric (mental) disease; depression, substance use disorders, and psychosis are the most relevant risk factors [3]. However, anxiety, personality-, eating-, and trauma-related disorders, as well as organic mental disorders, also contribute [4]. That means public health officials are faced with the challenge of identifying people who need help and encouraging them to get the assistance they need [5].

According to the European Regional Office of the World Health Organization's (WHO's), for many years, the top ten European countries in terms of the number of the suicide in various combinations include the six former Soviet republics (Table I). Ukraine is among them. However, Ukraine's suicide situation is reportedly improving (the suicide rate has dropped from 22.6 suicides per 100,000 population in 2005 to 14.8 cases in 2019). But firstly, suicides continue to occur and occupy a leading position among the so-called 
Table I. Position of a state in the list of top 10 European states on the rate of suicide [9]

\begin{tabular}{|c|c|c|c|c|c|c|c|}
\hline Year & $\frac{n}{3}$ & 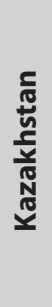 & 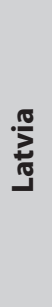 & 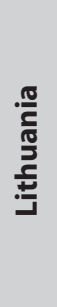 & 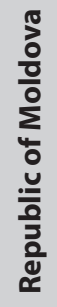 & 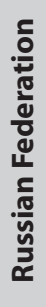 & \\
\hline 2001 & - & 4 & 5 & 1 & - & 2 & 9 \\
\hline 2002 & 3 & 4 & 5 & 1 & - & 2 & 8 \\
\hline 2003 & 3 & 4 & 7 & 1 & - & 2 & 8 \\
\hline 2004 & 3 & 4 & 6 & 1 & - & 2 & 9 \\
\hline 2005 & 3 & 4 & 5 & 1 & - & 2 & 8 \\
\hline 2006 & - & 3 & 6 & 1 & 9 & 2 & 7 \\
\hline 2007 & 4 & 2 & 8 & 1 & - & 3 & 6 \\
\hline 2008 & 3 & 2 & 5 & 1 & 10 & 4 & 8 \\
\hline 2009 & 2 & 3 & 5 & 1 & - & 4 & 7 \\
\hline 2010 & 2 & 3 & 6 & 1 & 7 & 5 & 8 \\
\hline 2011 & 4 & 3 & 6 & 1 & - & 5 & 7 \\
\hline 2012 & - & 3 & 4 & 1 & 10 & 5 & 7 \\
\hline 2013 & 4 & 2 & 7 & 1 & 8 & 3 & - \\
\hline 2014 & 4 & 2 & 3 & 1 & 8 & - & 5 \\
\hline 2015 & - & 3 & 4 & 1 & 7 & - & 6 \\
\hline 2016 & - & - & - & 1 & 3 & - & - \\
\hline
\end{tabular}

unnatural causes of death $[6, \mathrm{p} .76]$, or mortality from external causes [7, p. 78-82], and based on the abovementioned, the WHO qualifies the suicidal situation in our country as unfavorable [8]. And secondly, such modern negative phenomena as suicides among servicemen involving or being involved earlier in the military conflict in eastern Ukraine, cyberbulicide, a wave of child suicides, and more recently the global COVID-19 pandemic, etc. make their adjustments to the state of the suicidal situation in the state.

Thus, since the suicide rate is a kind of indicator of the state's public mental health situation, it simultaneously characterizes the prevalence of mental illness and the presence of disorders in the mental well-being of the population. Besides, the phenomenon of suicide must be analyzed not only in the retrospective view but also given the enormous socio-economic damage caused to society as a result of the premature death of a working-age person who committed suicide. The loss of human resources from suicide has its own value, its own price, which in the universal international payment system is often determined by the years of Years of Potential Life Lost (YPLL) and lost profits by society and the state in gross domestic product.

Of particular note is the problem of suicide mortality during the COVID-19 pandemic, which has changed the pace of life of many people around the world with the introduction of quarantine. After all, it was at this time that the crisis of loneliness worsened, the consequence of a person being in a state of depression, which in turn become one of the causes of suicide [10, p. 42]. Depression at this time is also caused by restrictions associated with lockdown: loss of a job, business, rented housing, financial difficulties, etc.

\section{THE AIM}

This article aims to analyze the rates of suicide as an indicator of public mental health, to consider the suicidal map of the territory of Ukraine (including to check the manifestation of such a territorial characteristic as the Albanian paradox); calculate the price of suicide for the socio-economic development of the Ukrainian state, consider the risks of suicide that have arisen as social and criminological consequences of the COVID-19 pandemic.

\section{MATERIALS AND METHODS}

The study was conducted in 2020 . The source base of this study is: 1) analytical materials of the Ministry of Health of Ukraine and the WHO;2) the information and analytical data of the General Prosecutor's Office of Ukraine; 3) information from the State Statistics Service of Ukraine and sectoral statistics for the period of 2015-2019, etc. Collected and grouped materials were processed using the technology of descriptive statistics. The article is based on dialectical, analytical, synthetic, comparative, statistical, cartographic, and sociological methods of research and the method of potential demography. Calculations and mapping were performed using computer programs Adobe Photoshop CS6 and QuickMap 2.2, Excel spreadsheets from Microsoft Office 2016. The theoretical basis of the article is specialized literature on medicine, suicidology, law, sociology, and cartography.

\section{RESULTS}

Public mental health is the mental health variations of importance exhibited by populations that consist of 'mental health promotion,' 'mental illness prevention', and 'treatment and rehabilitation' [11, p. 12]. WHO's stressed that there is no health without mental health. Mental health is central to the human, social and economic capital of nations and should therefore be considered as an integral and essential part of other public policy areas such as human rights, social care, education, and employment [12, p. 3].

Public mental health consists of a lot of elements. One of them is all issues, which consider suicide. In general, a suicide attempt is a clear indication that something is gravely wrong in a person's life. No matter the person's race or age, how rich or poor they are, it is true that most people who die by suicide have a mental or emotional disorder. The most common underlying disorder is depression, $30 \%$ to $70 \%$ of suicide victims suffer from major depression or bipolar (manic-depressive) disorder [13].

In Ukraine, the death rate from suicide in recent years averages $1.1 \%$ of the total number of deaths $[14]^{1}$. This fig-

\footnotetext{
${ }^{1}$ Footnote. In 2015 the death rate from suicide in Ukraine was 1,3\%, in 2016
} $-1,2 \%$, in $2017-1,1 \%$, in $2018-1,1 \%$, in $2019-1,1 \%$. 
Table II. Cases of intentional self-harm were registered in Ukraine in 2015-2019 [14]

\begin{tabular}{|c|c|c|c|c|c|c|c|c|c|}
\hline \multirow[t]{2}{*}{ Years } & \multicolumn{3}{|c|}{$\begin{array}{l}\text { Number of reported cases of } \\
\text { intentional self-harm that caused } \\
\text { the death of a person (suicide) }\end{array}$} & \multicolumn{3}{|c|}{$\begin{array}{l}\text { The level of intentional self-harm that } \\
\text { caused the death of a person (suicide) per } \\
100 \text { thousand population of Ukraine }\end{array}$} & \multicolumn{3}{|c|}{$\begin{array}{l}\text { Dynamics of intentional self- } \\
\text { harm that caused the death } \\
\text { of a person (suicide) (\%) }\end{array}$} \\
\hline & Total & Male & Female & Total & Male & Female & Total & Male & Female \\
\hline 2015 & 7575 & 6149 & 1426 & 17,72 & 14,38 & 3,34 & - & - & - \\
\hline 2016 & 6898 & 5619 & 1279 & 16,19 & 13,19 & 3,00 & $-8,94$ & $-8,62$ & 10,31 \\
\hline 2017 & 6488 & 5327 & 1161 & 15,30 & 12,56 & 2,74 & $-5,94$ & $-5,20$ & $-9,15$ \\
\hline 2018 & 6279 & 5172 & 1107 & 14,87 & 12,25 & 2,62 & $-3,22$ & $-2,91$ & $-4,65$ \\
\hline 2019 & 6190 & 5112 & 1078 & 14,75 & 12,18 & 2,57 & $-1,42$ & $-1,16$ & $-2,62$ \\
\hline Total & 33430 & 27379 & 6051 & - & - & - & - & - & - \\
\hline $\begin{array}{l}\text { Average } \\
\text { value } \\
\text { (abs.,\%) }\end{array}$ & $\begin{array}{c}6686 \\
-\end{array}$ & $\begin{array}{c}5476 \\
(81,9 \%)\end{array}$ & $\begin{array}{c}1210 \\
(18,1 \%)\end{array}$ & 13,77 & 12,91 & 2,85 & $-4,88$ & $-4,47$ & $-5,68$ \\
\hline
\end{tabular}

ure does not go beyond the global: as noted above, suicide mortality in the world is $1.4 \%$. A retrospective analysis of the suicidal situation in Ukraine, conducted based on data on the total number of cases of intentional self-harm resulted in death, by years of observation (2015-2019) and taking into account gender, allows to identify several trends and features of this situation (Table 2), which are as follows:

I. The rate of suicide decline in Ukraine has slowed significantly over the past five years (almost 6.3 times overall and seven and a half times for men), which is an alarming symptom.

II. As before, there are almost strict proportions between male and female suicide (men commit four out of five suicides). Moreover, the risk of suicidal behavior in men is higher in all age groups.

III. In contrast to the apparent decline in the dynamics of this phenomenon, the level of self-harm per 100,000 population of Ukraine remains almost stable, indicating a severe demographic crisis in Ukraine, associated with a sharp decline in the community as a whole.

IV. Compared to the WHO European Region data, women in Ukraine are less likely to commit suicide than in European countries, where this ratio is approximately $3 / 1$ [15]. At the same time, the fact that compared to the mid-90s of the twentieth century now women in Ukraine have become more likely to commit suicide (for example, the ratio of suicidal behavior in men and women in cities was 5.3: 1 , and in rural areas - 6.2:1) [16;17].

V. In Ukraine in recent years, contrary to European trends, suicide has dominated among the elderly aged 65+, although 15 years ago it was claimed that among young and middle-aged people, especially men, suicide is a leading cause of death [18, p. 75].

However, it should be noted that there is a distortion of official suicide statistics in Ukraine. This problem is quite common worldwide because, according to the WHO, only 80 Member States (out of 183!) Have high-quality data to assess suicide rates. Given the delicacy of the issue and the illegality of suicide in some countries, it is believed that incomplete reporting and misclassification are likely to be greater problems with suicide than with other causes of death [19]. Nowadays, in Ukraine, we also do not have accurate quantitative characteristics of suicide as a phenomenon because many facts are counted as cases of self-harm with undetermined intent. According to the International Classification of Diseases of the 10th revision, such cases include cases of self-harm, with the exception of poisoning, in the absence of indications of their nature (accidental or intentional) [20]. Thus, there is some unavailability or inadequacy of information to allow relevant experts to determine whether a particular incident is an accident, self-harm, or violence with the intention to kill or injure. In 2019, the number of cases of injuries with undetermined intent (except for alcohol poisoning) in Ukraine amounted to 5,559 [21, pp. 78-82]. The maximum that is done when detecting the fact of suicide is a conclusion about the absence of both the event and the composition of the crime of incitement to suicide that is made based on a few documents and insufficient information [22, p. 1]. By the way, in 2015, 86 cases of suicide were recorded in Ukraine; in 2016 - 133; in 2017 - 109; in 2018 - 114; in 2019 - 109 [23]. The suicidal situation in places of imprisonment is also tense. Thus, according to the WHO Regional Office for Europe, suicide is the cause of $13.5 \%$ of all deaths of convicts [24]. Simultaneously, the problem of suicide looks even more complicated concerning children and adolescents because many cases are "attributed" by society to curiosity, risk-taking, low level of life experience, carelessness, and so on. And the problem of adolescent suicide under the influence of communication on the Internet remains significantly undeveloped [25, p. 36]. And if it is almost impossible to hide the facts of adolescent suicide (both due to the natural reaction of parents and through wider communication), then "silence" to hide, in particular, from the public condemnation of suicide of the elderly, especially in rural areas, is quite common [19].

The suicidal map of the territory of Ukraine in 2019, conducted on the basis of official statistics and own calculations, gives grounds to claim that in terms of the intensity of suicide cases, the leading areas are still such regions as Kherson, Cherkasy, Vinnytsia, Zaporizhia, Kirovohrad. 


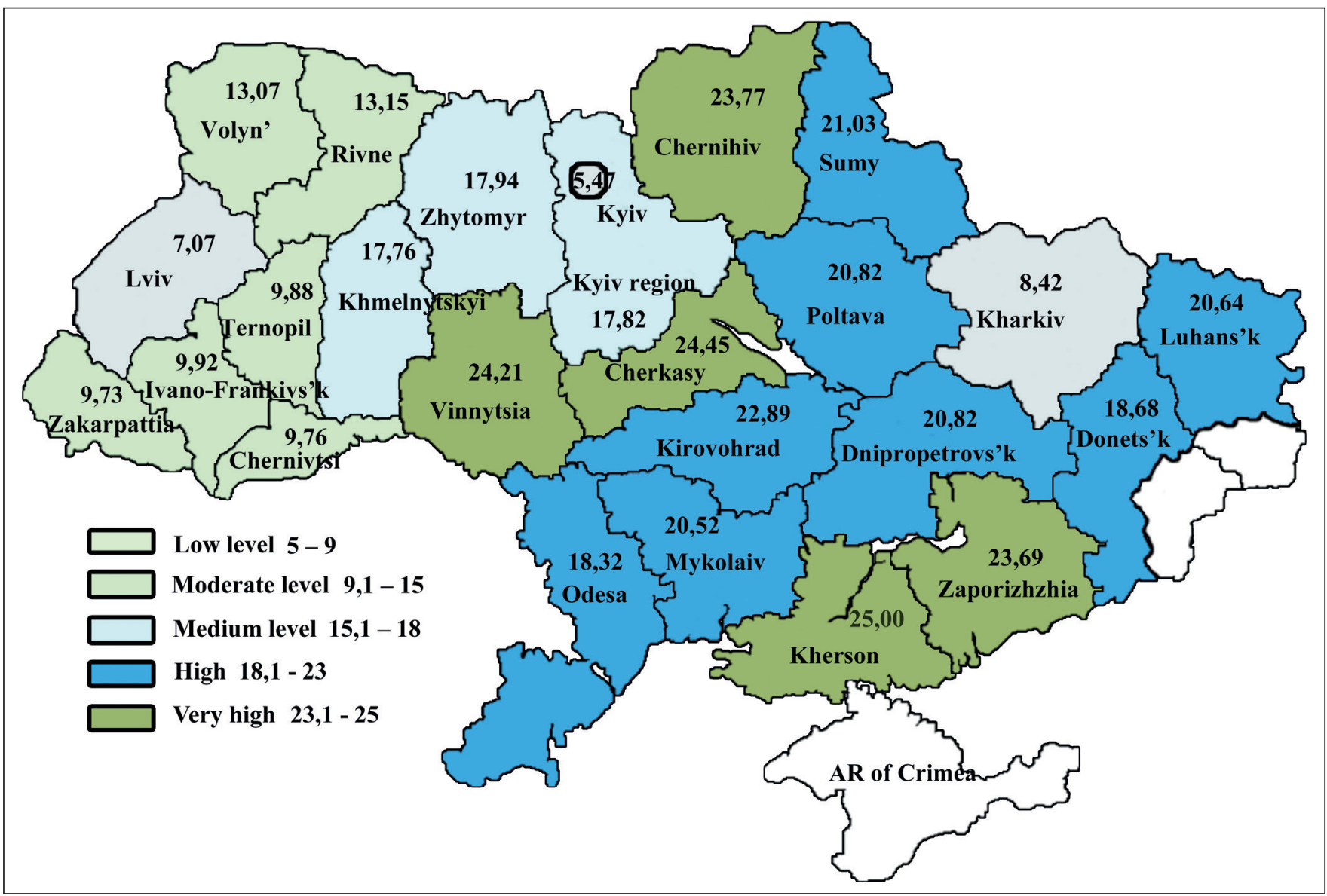

Fig. 1. Geography of suicide intensity in Ukraine per 100 thousand population in 2019.

At the same time, the situation in Chernihiv, Sumy and Poltava region has significantly deteriorated (Fig. 1). In these areas, the intensity of suicides is $20.82-25.0$ cases per 100 thousand population.

One of the research problems of modern suicidology is related to the explanation of the uneven distribution of suicide mortality rates on the European continent $[26$, p. 8$]$ because a long-term analysis of the territorial distribution of suicides in Europe gives ground to argue that there is a certain spatial pattern and it is resulting in the growing number of suicides in the direction from the southwest (the Mediterranean and the British Isles) to the northeast of the continent (central and northeastern regions of Europe). In the specialized literature, this pattern is called the Yugoslav or Albanian paradox [26, p. $8 ; 27 ; 28]$. In this regard, one of the goals of this study was to address the question: does this pan-European (regional) phenomenon work in Ukraine, as is the case in France, Italy, Russia, Belarus, etc.? (Fig. 1).

The above map clearly shows that the suicidal picture in Ukraine "unfolds" in space in a peculiar way, different from the European trend. The situation in the east of the country, which indicates relative prosperity in terms of suicidal activity in one of the largest regions of Ukraine - Kharkiv region, is interrupted in the central part of Ukraine's map by a vertical axis in the direction of "North-South." This territorial segment of the country (Kherson, Chernihiv,
Cherkasy, Vinnytsia, Zaporizhia, Kirovohrad, Sumy, and other regions) that a high and very high level of suicides is observed, which contradicts the principle of the Albanian paradox, the vector of which, as was mentioned before, shows a decrease in suicidal activity in North to South direction in the European part of the continent. In these areas, the saturation of territories by suicide is almost twice as high as the national parameters and three to four times higher than those included in the group of relatively low suicide intensity. At the same time, one cannot fail to note the very tense suicidal situation is in eastern Ukraine, namely in the territory of the Luhansk region controlled by the Ukrainian authorities, which is adjacent to the area of military activity. More than a thousand military conflict participants in the east of our country have committed suicide in a few years. These are mostly young people born in 1995-1998 [28].

The geographically outlined suicidal situation in Ukraine has been observed for at least the last 4-5 years [29]. Before that, there was statistically confirmed information that the difference in suicide rates was observed on the East-West axis and testified to the tense suicidal situation with the highest mortality rate from auto aggression in industrial areas of the country in the East and in Chernobyl-affected areas with its noticeable softening in agricultural regions closer to the western borders of Ukraine [30, p. 30]. Thus, within the territory of individual countries, the Albanian 
Table III. Calculation of lost years of life (including able-bodied) for persons who committed self-harm in 2019

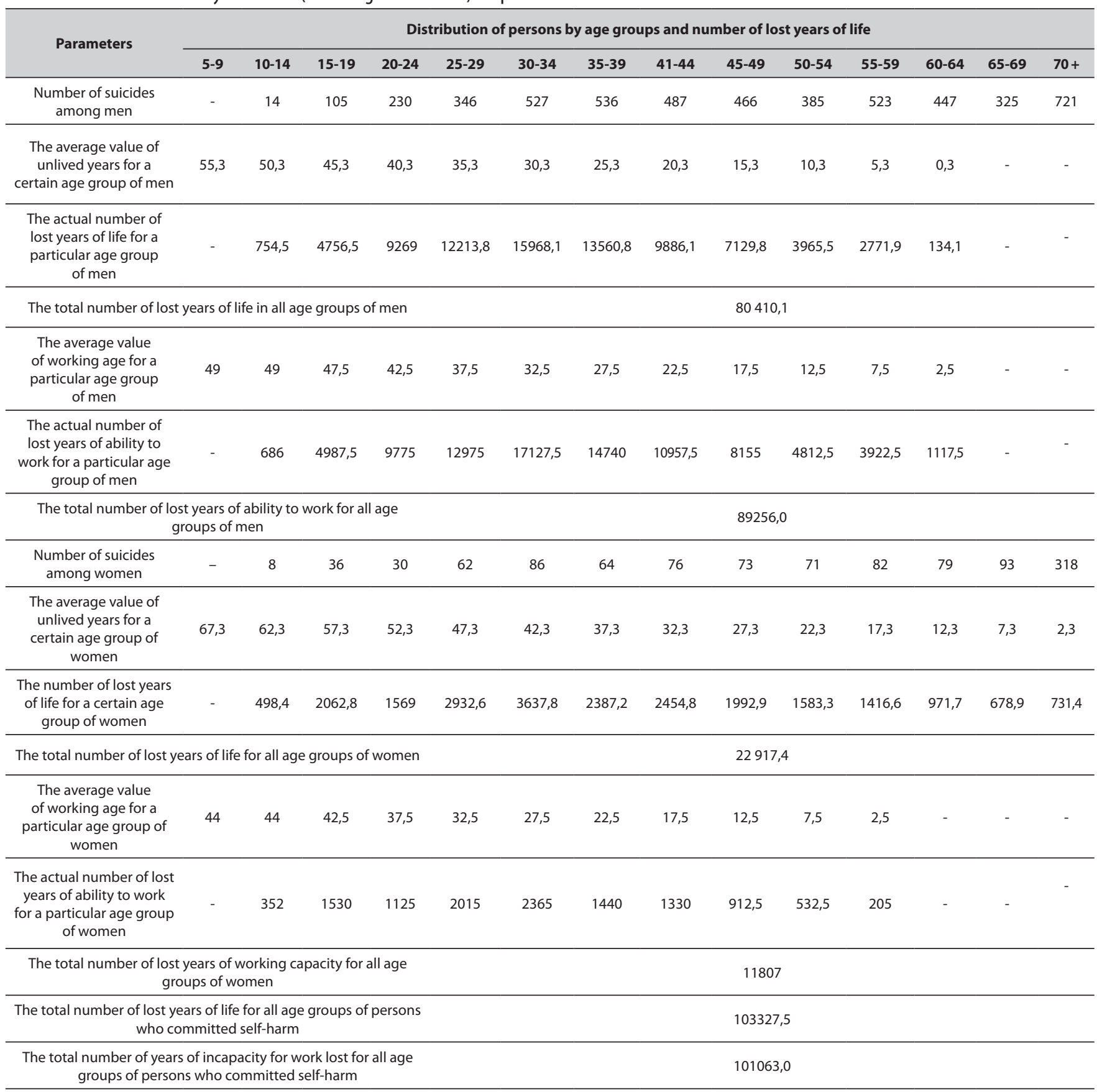

paradox can be leveled, as is the case in Ukraine. However, in terms of the area, it is the largest country in Europe, whose territory is entirely within this continent. Probably, such deviation from the European trend is due to the existence of a unique causal complex of many different regional factors (socio-economic, military-political, cultural, environmental, etc.), which affects the suicidal picture and is specific to this country.

Committing suicide is a deliberate shortening of age by a person, reducing the number of potentially lived years. In this regard, it should be emphasized that an essential indicator of the socio-economic dimension of any state's well-being is the preservation of human potential, which can produce a certain amount of gross domestic product at a given time. The indicator of the produced product depends, in particular, on the length of human life and the number of working years of human potential depending on gender.

In WHO's reports, the effects of suicide are expressed in standardized units, namely: in years of potential life loss (YPLL) due to premature death, calculated as the sum of the differences between a predetermined endpoint and the ages of death for those who died before that end point; the two most commonly used end points are age 65 years and average life expectancy [31, pp. 3-33]. To determine the cost of suicide in Ukraine, we calculated the YPLL for any age group of suicides in Ukraine based on the average of the corresponding five-year interval and the average life expectancy for men and women separately. Thus, currently, 
Table IV. Unearned GDP for all unlived working life of persons who committed self-harm in 2019

\begin{tabular}{|c|c|c|c|c|c|c|c|c|c|c|c|c|c|c|}
\hline \multirow{2}{*}{ Parameters } & \multicolumn{14}{|c|}{ Distribution of persons by age groups and unearned GDP for unlived working life } \\
\hline & $5-9$ & $10-14$ & $15-19$ & $20-24$ & $25-29$ & $30-34$ & $35-39$ & $41-44$ & $45-49$ & $50-54$ & $55-59$ & $60-64$ & $65-69$ & $70+$ \\
\hline $\begin{array}{l}\text { Unearned GDP for } \\
\text { all unlived working } \\
\text { life for a certain age } \\
\text { group of men }\end{array}$ & - & 4875020 & 71667875 & 24421750 & 1227045750 & 1619747675 & 1393961800 & 1036250775 & 71218350 & 55118125 & 370950825 & 105681975 & - & - \\
\hline \multicolumn{9}{|c|}{$\begin{array}{l}\text { Unearned GDP for all unlived working life for all age } \\
\text { groups of men (UAH) }\end{array}$} & \multicolumn{6}{|c|}{8440939920} \\
\hline $\begin{array}{l}\text { Unearned GDP for } \\
\text { all unlived working } \\
\text { life for a certain age } \\
\text { group of women }\end{array}$ & - & 33288640 & 144692100 & 106391250 & 90558550 & 23658050 & 36180800 & 25778100 & 86295125 & 0358525 & 19386850 & - & - & - \\
\hline \multicolumn{9}{|c|}{$\begin{array}{l}\text { Unearned GDP for all unlived working life for all age } \\
\text { groups of men (UAH) }\end{array}$} & \multicolumn{6}{|c|}{1116587990} \\
\hline \multicolumn{9}{|c|}{$\begin{array}{l}\text { Unearned GDP for all unlived working life for all age } \\
\text { groups of persons who committed self-harm (UAH) }\end{array}$} & \multicolumn{6}{|c|}{9557527910} \\
\hline
\end{tabular}

the average life expectancy in Ukraine for men is 62.8 years, for women - 74.8 years [32]. Concerning the calculation of lost years of ability to work, we took into account the number of unlived years to retirement age for each age group, which in our country is 65 years for men and 60 years for women. At the same time, the minimum working age in Ukraine is generally 16 years. It is interesting to note that nowadays, for Ukrainian men, the age at which a person can retire exceeds the average life expectancy (!). Therefore, there is a certain imbalance between YPLL and lost years of employment because the latter's total value exceeds the actual cost of life expectancy by men. In such a situation, there is a severe problem for Ukraine of premature depletion of the labor force to the endpoint of the working-age specified in the national labor legislation. After all, with any sudden death, labor reserves are devastated, investment in people is devalued [33].

Our calculations show that the total number of YPLLs for men who committed suicide in 2019 is 80,410.1 years, and the working-age - $87,838.5$. For women, the corresponding figures are $22,917.4$ and 11,807 , respectively. In total, the number of YPLLs for male and female suicides in Ukraine is $103,327.5$, and the number of working years is 101063,0 .

When calculating the amount of GDP not received as a result of suicide, we again took into account the number of unlived years for each age group before retirement age and the quantitative indicator of per capita income per year. These losses were calculated at the rate of 94,570 UAH per person (2019) [34]. So, if there were no premature death, then during their working life, men who died from suicide only in 2019 could produce a GDP of UAH 89256,0 , which in terms of US dollars is about 313 billion (!) Unearned GDP for all unlived working life of women who committed suicide in the analyzed year reaches UAH $1,116,587,990$ (over USD 41 billion). In total, the losses for Ukraine from the unlived life of those who died as a result of suicide in 2019 are equal to UAH 9557527910 (almost USD 354 billion) (Table III). The average damage to the state and society's productive functioning from the death of one person is about 58 thousand US dollars. At the same time, the central part of unearned GDP due to unlived life falls on men who committed suicide at working age or even before reaching that age.

Table IV. Unearned GDP for all unlived working life of persons who committed self-harm in 2019

\section{DISCUSSIONS}

About 800,000 people commit suicide each year worldwide. Each suicide affects an average of 135 other people: relatives, friends, acquaintances of the deceased. That's 108 million people a year [35]. The consequences of this interaction are different: from longing for the dead to depression. Information about a person's suicide also affects ordinary citizens, can cause them a state of anxiety, insecurity, etc., which affects not only the prevalence of mental illness but also the state of mental well-being of the population. Therefore, the suicide mortality rate can be defined as a kind of indicator of public mental health in the state.

Identification and analysis of statistical material related to suicide, compared with other social changes, can be an indicator of favorability of social conditions, the level of social tension, and society's functioning as a whole [36, p. 76]. Since December 2019, the world has been affected by gradual (and sometimes abrupt) changes in public life related to the SARS-Cov-2 virus pandemic and the introduction of state measures to stop its spread. This situation also affects those who are prone to suicide.

Suicide is a multifactorial process. In addition to the immediate causes that a person considers to be the impetus for suicide, several risks contribute to suicidal thoughts. The risk factors common across health care settings include mental illness; having previously attempted suicide; recent suicide attempt; suicidal thoughts or behaviors; a family history of suicide or psychiatric illness; on antidepressants; physical health problems, including central nervous system disorders such as traumatic brain injury; diagnosis of delirium or dementia; chronic pain or intense acute pain; poor prognosis or the prospect of certain death; social stressors such as financial strain, unemployment or loss of economic independence; disability; trauma; divorce or other relationship 
problems; hopelessness; and substance abuse [37; 38]. Older adults are prone to additional suicide risk factors, including declining health, loneliness, and recent bereavement [38; 39]. In addition to these risks, the COVID-19 pandemic presents new ones or changes existing ones' content. Foreign researchers suggest identifying the following risks of suicide during a COVID-19 pandemic:

1) selective and indicated interventions (target individuals who are at heightened risk of suicide or are actively suicidal): mental illness; experience of suicidal crisis;

2) universal interventions (target the whole population and focus on particular risk factors without identifying specific individuals with those risk factors): financial stressors- domestic violence; alcohol consumption; isolation, entrapment, loneliness, and bereavement; access to means; irresponsible media reporting [40].

The formation of suicidal behavior in vulnerable populations in the COVID-19 era occurs primarily under the influence of factors such as uncertainty, social isolation, and economic problems [41]. The risk of suicide by vulnerable people (including individuals with preexisting psychiatric disorders, low-resilient people, individuals who reside in high COVID-19 prevalence areas, people who have a family member or friend who has died of COVID) increases when these factors affect in combination with exacerbation of preexisting psychiatric disorders, depressive disorders, anxiety disorders, alcohol, and other substance use disorders and other psychiatric conditions [41].

Thus, the study of the suicidal situation during COVID-19 allows concluding the state of public mental health in this period, to make predictions about similar indicators in case of future pandemics and, considering their features, to develop suicide prevention work in the current and comparable possible period.

Regarding the further study of the problem of suicides in Ukraine, it is necessary to deeply research the issue of creating a so-called suicide passport of the regions of Ukraine (VZ Rothschild-Varibrus et al.) [43] to see regional features of the mortality situation in certain areas as a result of suicides, to find out the reasons for possible differences and to develop appropriate suicide prevention strategies at both the state and local levels.

Of particular note is the additional collection of arguments to explain the territorial deviations of the suicidal situation in Ukraine from the pan-European trend of a significant decrease in the number of similar facts in Europe from North to South, called the Albanian paradox.

Studying the specifics of suicide situation (the causes in particular) and developing measures for its prevention, special attention should be paid to a comprehensive study of such a socially dangerous phenomenon as cyberbulicide, which can be a cause of incitement to suicide, especially regarding minors, through the use of Internet technology (S. Bauman et al. (2013), Primack AJ et al. (2017), Hinduja S. et al. (2010), Bychkova AM (2018)) [44; 45; 46; 47] The problem of suicide in the light of the global pandemic COVID-19 as one of its consequences of a social and criminological nature acquires special significance.

\section{CONCLUSIONS}

The suicide mortality rate as an indicator of public mental health in Ukraine shows that in our country, suicide mortality does not exceed the global figure (1.1\% in Ukraine vs. $1.4 \%$ in the world).

At the same time, in 2019, suicides accounted for almost $21 \%$ of deaths from external causes among Ukraine's population. The most intense suicidal situation is observed in the central part of the country's geographical map along the imaginary vertical axis "North-South" (Kherson, Chernihiv, Cherkasy, Vinnytsia, Zaporizhia, Kirovohrad, Sumy, Poltava, Dnipropetrovsk, Mykolaiv regions). The situation in the largest country in Europe, whose territory is entirely in the European part of the continent, contradicts the principle of the Albanian paradox described in the literature, according to which the vector of suicidal activity indicates its decline from North to South of the European part of the continent.

People's death as a result of suicide in just one year causes colossal material and human losses to Ukraine. Thus, the number of YPLL due to premature death in 2019 is $103,327.5$, and the number of working years - 101063,0. In material terms, the loss from unlived life is almost 354 billion US dollars. The central part of these losses is caused by the death of men of working age.

In addition to the main factors of suicide (mental illness, depressive disorders, etc.) during the COVID-19 pandemic, many additional factors increase the risk of suicide among individuals who are at heightened risk of suicide or are actively suicidal, and among the general population.

\section{REFERENCES}

1. Lyubov E.B., Morev M.V., Falaleeva 0.I. Suicidy: socio-ekonomicheskoe bremya v Rossii. [Suicides: a socio-economic burden in Russia.] Medicinskaya psihologiya v Rossii: elektron. nauch. zhurn. 2013;2(19). Available from: http://medpsy.ru [reviewed 2020.08.12] (Ru).

2. Shkuro V.V. Suitsydalnist v Ukraini: kryminolohichna kharakterystyka ta protydiia: monohrafiia [Suicide in Ukraine: criminological characteristics and counteraction: monograph] za nauk. red. Yu. V. Orlova; Kryminolohichna asotsi-atsiia Ukrainy. Kharkiv: Panov, 2017. 262 s. (Ua).

3. Bachmann S. Epidemiology of Suicide and the Psychiatric Perspective. Int. J. Environ. Res. Public Health. 2018;15:1425. doi: 10.3390/ijerph15071425.

4. Brådvik L. Suicide Risk and Mental Disorders. Int J Environ Res Public Health. 2018 Sep; 15(9): 2028. doi: 10.3390/ijerph15092028

5. Mental Illness and Public Health. Available from:https://mphdegree.usc. edu/blog/mental-illness-and-public-health/ [reviewed 2020.08.12].

6. Linskyil.V., Bacherykov A. M., Lakynskyi R.V. ta in. Henderni osoblyvosti zavershenykh suitsydalnykh sprob v m. Kharkovi (2008-2011 rr.). [Gender features of completed suicide attempts in Kharkiv (2008-2011)] Ukrainskyi visnyk psykhonevrolohii. 2014; 22; 1 (78): 76-80 (Ua).

7. Pryrodnyi rukh naselennia Ukrainy. Statystychnyi zbirnyk. [Natural movement of the population of Ukraine. Statistical collection.] Kyiv: Derzhavna sluzhba statystyky Ukrainy, 2020. 148 s. (Ua).

8. Rejting stran po urovnyu samoubijstv. [Country ranking by suicide rate.] Available from: https://nonews.co/directory/lists/countries/ suicide-rate. [reviewed 2020.08.20] (Ru). 
9. European Health Information Gateway. Available from: https://gateway. euro.who.int/en/indicators/hfamdb_771-sdr-suicide-and-intentionalself-harm-per-100-000/visualizations/\#id=31321\&tab=table [reviewed 2020.08.20].

10. Kalinina A. V. Pandemiia virusu vs pravoporiadok: kryminolohichnyi prohnoz. [Virus pandemic vs law and order: criminological prognosis] Pytannia borotby zi zlochynnistiu. 2020;39:39-45. (Ua).

11. Annual Report of the Chief Medical Officer 2013, Public Mental Health Priorities: Investing in the Evidence. Available from: https://mrc. ukri.org/documents/pdf/chief-medical-officer-annual-report-2013/ [reviewed 2020.08.20].

12. WHO European Ministerial Conference on Mental Health Facing the Challenges, Building Solutions (Helsinki, Finland, 12-15 January 2005). Available from: https://www.euro.who.int/__data/assets/ pdf_file/0008/88595/E85445.pdf. [reviewed 2020.08.20].

13. Paris S. Strom, Robert D. Strom. Adolescents In The Internet Age, Teaching And Learning From Them, 2nd Edition. 2014. 466 p.

14. Derzhavna sluzhba statystyky Ukrainy. [State Statistics Service of Ukraine]. Available from: http://www.ukrstat.gov.ua [reviewed 2020.08.20] (Ua).

15. Preventing suicide: a global imperative. Geneva: World Health Organization, 2014.97 p.

16. Mokhovikov A.N. Suicide in Ukraine. Crisis. 1994; 15 (3): 137

17. Mokhovikov A., Donets 0. Suicide in Ukraine: epidemiology, knowledge, and attitudes in the population. Crisis. 17 (3): P. 128-134 (1996). doi: 10.1027/0227-5910.17.3.128.

18. Mental health:facing the challenges, building solutions: reportfrom theWHO European Ministerial Conference. World Health Organization, 2005. 182p.

19. Rynhach N. Samohubstva v Ukraini: chy mozhna unyknuty? [Suicide in Ukraine: can it be avoided?] Available from: https://zn.ua/ukr/ SOCIUM/samogubstva-v-ukrayini-chi-mozhna-uniknuti-340786_. html [reviewed 2020.08.25] (Ua).

20. ICD-10 Version: 2019. Available from: https://icd.who.int/ browse10/2019/en\#/Y10-Y34. [reviewed 2020.08.25].

21. Pryrodnyi rukh naselennia Ukrainy za 2019 rik: statystychnyi zbirnyk [Natural movement of the population of Ukraine in 2019: a statistical collection] vidp. za vypusk Timonina M. B.. Kyiv: Derzhavna sluzhba statystyky Ukrainy, 2020. 148 s. (Ua).

22. Shestopalova L.M. Samohubstvo ta dovedennia do samohubstva: zakhody protydii. [Suicide and leading to suicide: countermeasures] : avtoref. ... kand. yuryd. nauk: 12.00.08/ Nats. akad. vnutr. sprav. Kyiv, 2001.22s. (Ua).

23. Yedynyi zvit pro kryminalni pravoporushennia po derzhavi za sichenhruden 2015,2016,2017,2018ta 2019rr. :stat. inform. Hen. prokuratury Ukrainy. [The only report on criminal offenses in the country for JanuaryDecember 2015, 2016, 2017, 2018 and 2019: stat. inform. Gene. Prosecutor's Office of Ukraine] Available from: https://www.gp.gov. ua/ua/stst2011.html?dir_id=113287\&libid=100820\&c=edit\&_c=fo\# [reviewed 2020.08.25] (Ua).

24. Klyuchevye fakty i cifry dlya Evropejskogo regiona V0Z. [Key facts and figures for the WHO European Region.] Available from: https:// www.euro.who.int/ru/media-centre/sections/press-releases/2019/ new-who-report-ignoring-the-health-of-people-in-prisons-nowcomes-at-a-high-cost-for-society-later/some-key-facts-and-figuresfor-the-who-european-region. [reviewed 2020.08.30] (Ru).

25. Batyrhareieva V.S. Samohubstva ditei i pidlitkiv v Ukraini: vplyv Internetmerezhi. [Suicides of children and adolescents in Ukraine: the impact of the Internet] Pytannia borotby zi zlochynnistiu: zb. nauk. pr. / redkol.: V.I. Borysov ta in. Kharkiv: Pravo, 2019: 35-46 (Ua).
26. Razvodovskij YU.E., Kondrichin S.V. Regional'nyj pattern smertnosti ot samoubijstv v evropejskoj chasti Rossii i Belarusi. [Regional pattern of suicide mortality in the European part of Russia and Belarus] Suicidologiya. 2015; 6(18); 1: 8-18. (Ru).

27. Suicidal behaviour in Europe: The situation in the 1990s.. Copenhagen: World Health Organization, Regional Office for Europe, 1998. EUR/ICP/ HPSA $010403.38 p$.

28. Kerkhof J., \& Clark, D. Stability of suicide rates in Europe. Crisis. 1993; 14(2): 50-52.

29. Bol'she tysyachi uchastnikov ATO pokonchili zhizn' samoubivstvom. [More than a thousand ATO participants committed suicide.] Available from: https://www.unian.net/war/10092818-bolshe-tysyachiuchastnikov-ato-pokonchili-zhizn-samoubiystvom.html [reviewed 2020.08.30] (Ru).

30. Batyrgareieva Vladyslava S., Kalinina Alina V., Babenko Andriy M. Energy infrastructure objects of Ukraine as a public health threat: criminological analysis. Wiadomości Lekarskie. 2019;Tom LXXII;nr 12 cz. II: 2434-2456.

31. Kondrichin S.V., Lester D. Suicide in the Ukraine. Crisis. 2002;23(1):32-3. doi: 10.1027//0227-5910.23.1.32.

32. Principles of Epidemiology in Public Health Practice: Self-study Course SS1978. Third Edition. Atlanta: U.S. Department of Health and Human Services, 2006 (Updated May 2012). 511 p.

33. Chyselnist naselennia Ukrainy 2019. [Population of Ukraine 2019] Available from: https://sylnaukraina.com.ua/novini/chiselnistnaselennya-ukraïni-2017.html. [reviewed 2020.08.30] (Ua).

34. Lyubov E.B., Morev M.V., Falaleeva 0.I. Ekonomicheskoe bremya suicidov $v$ Rossijskoj Federacii. [The economic burden of suicides in the Russian Federation] Suicidologiya. 2012; 3:3-10. (Ru).

35. Zrostannia VVP Ukrainy v 2019 rotsi spovilnylosia do 3,2\% - Derzhstat. [Ukraine's GDP growth slowed to 3.2\% in 2019-Gosstat] Available from: https://ua-news.liga.net/economics/news/zrostannya-vvp-ukraini-v2019-rotsi-spovilnilosya-do-32---derjstat [reviewed 2020.08.30] (Ua).

36. Shtaudenmaier R. Samohubstva u chasy pandemii: sotsialni obmezhennia zahostriuiut problemu. [Pandemic suicides: social constraints exacerbate the problem.] Available from: https://p. dw.com/p/3iGJB [reviewed 2020.09.05] (Ua).

37. Linskyil.V.ta in. Henderni osoblyvostizavershenykh suitsydalnykh sprob v m. Kharkovi (2008-2011 rr.). [Gender features of completed suicide attempts in Kharkiv (2008-2011)] Ukrainskyi visnyk psykhonevrolohii. 2014;22;1(78):76-80 (Ua).

38. Tischler CL, Reiss NS: Inpatient Suicide: Preventing a Common Sentinel Event. General Hospital Psychiatry, 2009;31:103-109.

39. The Joint Commission Sentinel Event Alert Issue 46, November 17, 2010. Available from: www.jointcommission.org. [reviewed 2020.09.05].

40. Hicks LE, Wood N: Depression and Suicide Risks in Older Adults: A Case Study. Home Healthcare Nurse, September 2009;27(8):482-487

41. Gunnell D., Appleby L., Arensman E. et al. Suicide risk and prevention during the COVID-19 pandemic. Lancet Psychiatry 2020; published online April 21. doi: 10.1016/S2215-0366(20)30171-1.

42. Sher L. The impact of the COVID-19 pandemic on suicide rates. QJM: An International Journal of Medicine, 2020; 113; 10: 707-712. doi: 10.1093/qjmed/hcaa202.

43. Rotshil'd-Varibrus V.Z., Korzhenevskij S. V., Mihal'chuk O. YA., Ermakov L. V., Konarev V. I., Vovk V. I. Suicidologicheskij pasport territorial'noj obshchiny kak opornyj element nacional'noj strategii prevencii samoubijstva v Ukraine. [Suicide passport of the territorial community as a pillar of the national strategy for the prevention of suicide in Ukraine] Ukraïns'kij visnik psihonevrologiï. 2019; 27; 2 (99):52-55. 
44. Bauman S., Toomey R.B., Walker J.L. Associations among bullying, cyberbullying, and suicide in high school students. Journal of Adolescence. 2013; 36:341-350.

45. Primack A.J., Johnson K.A. Student cyberbullying inside the digital schoolhouse gate: Toward a standard for determining where a "School" is. First Amendment Studies. 2017;51(1) Is. 1: 30-48. doi: 10.1080/21689725.2016.1278177.

46. Hinduja S., Patchin J. Bullying, Cyberbullying and Suicide. Archives of Suicide Research. 2010; 14 (3):206-221.

47. Bychkova A.M., Radnaeva E.L. Dovedenie do samoubijstva posredstvom ispol'zovaniya internet-tekhnologij: social'nopsihologicheskie, kriminologicheskie i ugolovno-pravovye aspekty. [Driving to suicide through the use of Internet technologies: sociopsychological, criminological and criminal law aspects] Vserossijskij kriminologicheskij zhurnal. 2018;12;1:101-115. doi: 10.17150/25004255.2018.12(1).101-115.

The scientific article was prepared for the project "Socio-legal and criminological consequences of the spread of pandemics and ways to eliminate them in Ukraine" (the registration number: 2020.01 / 0155) is supported by the National Research Foundation of Ukraine.

\section{ORCID and contributionship:}

Vladyslava S. Batyrgareieva: 0000-0003-3879-2237 A, B, C, D, E, F Alina V. Kalinina: 0000-0001-8015-0807 A, D, E, F

Andriy M. Babenko: 0000-0002-9498-2484 ${ }^{A, B}$

\section{Conflict of interest:}

The Authors declare no conflict of interest.

\author{
CORRESPONDING AUTHOR \\ Vladyslava S. Batyrgareieva \\ Academician Stashis Scientific Research Institute \\ for the Study of Crime Problems of the \\ National Academy of Law Sciences of Ukraine, \\ Kharkiv, Ukraine \\ tel: +380505830788 \\ e-mail:vladis2229@yandex.ru
}

Received: 28.08 .2020

Accepted: 26.11 .2020

A - Work concept and design, B - Data collection and analysis, C - Responsibility for statistical analysis,

D - Writing the article, $\mathbf{E}$ - Critical review, $\mathbf{F}$ - Final approval of the article 